\title{
SUBJECTIVE WELL-BEING AND HEALTHY BEHAVIOR OF ELDERLY WITH DEMENTIA ALZHEIMER'S (A PHENOMENOLOGICAL STUDY)
}

\author{
Aprillia Mauren Pariama ${ }^{1}$, Yulius Yusak Ranimpi ${ }^{2}$, Adi Setiawan ${ }^{3}$ \\ Correspondence: 832016005@student.uksw.edu \\ ${ }^{1}$ Postgraduate Program in Psychology Sciences of Universitas Kristen Satya Wacana. Salatiga, Indonesia \\ ${ }^{2}$ Faculty of Theology Universitas Kristen Satya Wacana, Salatiga, Indonesia \\ ${ }^{3}$ Faculty of Mathematics and Science Universitas Kristen Satya Wacana, Salatiga, Indonesia
}

\begin{abstract}
Article History:
Received: November 5, 2019

Accepted: June 25, 2020

Published: July 1, 2020
\end{abstract}

\section{Cite this as:}

Pariama AP, Ranimpi $Y Y$,

Setiawan A. Subjective well-being and healthy behavior of elderly

with dementia alzheimer's ( a phenomenological study). Malang Neurology Journal; 2020.6:8287.

http://dx.doi.org/10.21776/ub.mnj .2020.006.02.7

\begin{abstract}
Background: Dementia is a syndrome caused by decreased cognitive function due to aging, genetics, vascular disease and low physical and cognitive activities. Alzheimer's is the most common cause of dementia. Despite experiencing holistic changes in their lives, elderly with dementia Alzheimer's are entitled to well-being. Measurement of Subjective Well-being (SWB) is used to determine the wellbeing state of elderlies.

Objective: The purpose of this study is to analyze the expression of Subjective well-being (SWB) and the healthy behavior of elderlies with dementia Alzheimer's.

Methods: This study uses a qualitative phenomenological approach with a descriptive hermeneutics type. The data collection was done by in-depth interview techniques with the type of auto-anamnesis, observed, and family statements. The data analysis process was carried out in 3 stages (Verbatim, initial and focused coding, determination of categories were made in the form of themes). Data validity test used data triangulation techniques.

Results: Participants in this study are 3 elderlies age 75 and 76 years who had mild dementia Alzheimer's. This condition affects participants ability in expressing their SWB and health behavior that are described in physical disorders, life satisfaction, satisfaction with important domains, positive influence, behavior change, treatment-seeking, and cognitive failure.

Conclusion: Reported high subjective well-being is closely related to the low level of unpleasant emotions during their life journey. Healthy behavior is strongly influenced by knowledge, demographic factors, personal goals and values, social influence, and access to health services. Two participants managed to express SWB and healthy behaviors better than one participant.
\end{abstract}

Keywords: Alzheimer's, dementia, subjective well-being, cognitive, elderly, healthy behavior.

\section{Introduction}

Individuals are referred to as elderly once they reached the age of 60 y.o. or more. ${ }^{1}$ Entering this stage of life, individuals will experience changes in aspects such as cognitive, financial, spiritual, psychology ${ }^{2}$ and physical disruption (malnutrition, dementia, balance and fall). ${ }^{3}$ World Health Organization (WHO $)^{4}$ reported that in 2015 , the highest number of health disruption on the elderlies are stress, fall, diabetes and dementia. Dementia is a term used to describe the symptoms of brain disorders that are characterized by memory loss, cognitive disorders, confusion, changes in behavior, and emotional disorders. ${ }^{5}$ This syndrome is caused by aging, family history, vascular disease ${ }^{6}$, and low physical and cognitive activity. ${ }^{7}$ Alzheimer's is the most common cause of dementia and it is a progressive disease caused by abnormal proteins such as 'plaque' and 'wrinkled' in the brain. ${ }^{8,9}$ This condition results in a lack of some important chemicals in the brain that cause ineffectiveness in transmitting signals to the brain, loss of connection so that nerve cell become death and loss of brain tissue. ${ }^{7}$ The elderly with dementia have memory loss, difficulty in moving, disorientation of time and place, difficulty in communication, difficulty in understanding visuospatial, difficulty in decision making, separate (oneself), behavioral and emotional changes. ${ }^{10}$ These symptoms cause them to experience functional disability ${ }^{10}$, lack of fulfillment of physiological, loving and being loved, security and safety needs, and low self-esteem. ${ }^{11}$

Holistic changes experienced by the elderlies should receive special attention from the community and medical staff since government has been trying to enhance the elderlies' welfare due to the increasing life expectancy. ${ }^{12}$ Republic of Indonesia's Law 1998, chapter $1^{13}$ has also regulate elderlies' welfare in providing continuous protection and service for a better living standard. Furthermore, the Government Regulation on the Implementation of Efforts to Improve Social Wellbeing of Elderly ${ }^{14}$ also clearly states that efforts to improve the wellbeing of the elderly are carried out by and are the responsibility of the government, the community, and families. 
Subjective wellbeing (SWB) and individual-collective effort are approaches to measure wellbeing. SWB refers to the expression of all incident in the life on the environmental, moral and cultural aspects. ${ }^{15}$ Individual and collective efforts refer to education related to the healthy lifestyle of health workers and interventions to implement healthy behavior. ${ }^{16}$ In the context of improving wellbeing on the elderly, expressing SWB and healthy behavior will be difficult if applied to the elderly with dementia. It becomes difficult due to the decline in cognitive function that causes the elderly to experience language impairment, decreased memory and thinking; and behavior changes. ${ }^{15}$

Based on preliminary and literature studies, the issue of dementia seems to be under-explored because it is considered as a natural happening in the aging process. ${ }^{17}$ In addition, public awareness and understanding of dementia Alzheimer's is still lacking. ${ }^{18}$ Survey indicates the uncertainty in number of elderly people with dementia Alzheimer's in Indonesia. ${ }^{17}$ Considering the wellbeing of the elderly is a priority and a responsibility of the community and the government which can be determined through SWB and healthy behavior. The challenge faced at the pragmatic level is how to strive for the wellbeing and healthy behavior of the elderly with dementia Alzheimer's? It is very important to be aware that this syndrome causes decline in cognitive function and makes the elderly experience behavioral changes. Based on that explanation, the purpose of this study is to analyze the expression of SWB and the healthy behavior of the elderlies with dementia.

\section{Methods}

This study uses a qualitative phenomenological approach with a descriptive hermeneutics type ${ }^{19}$ Research participants are 3 elderlies age 75 and 76 years who had mild dementia Alzheimer's. The data collection process began from March 1, 2018, to March 7, 2019. Characteristics of the participants were obtained through direct interviews with participants and caregiver, measurements by Mini-Mental State Examination (MMSE) ${ }^{20}$, symptom analysis based on references from the Diagnostic and Statistical Manual of Mental Disorder fifth Edition (DSM V) ${ }^{21}$ and the medical history reports from doctors. Primary data collection was done by in-depth interview techniques (2-3 times a week) with the type of auto-anamnesis not structured but based on the points of this research's topic. Behavior and gestures / facial expressions / inflection/ and participant research's body posture (this is done during interviews or not) were also observed. Secondary data were obtained from family statements /research participants companions. The data analysis process ${ }^{19}$ was carried out in 3 stages, namely: first, the data obtained was written in the form of verbatim and numbered on field notes. The next stage was determination of initial and focused coding, and then determination of categories. In the last stage, the similar categories were made in the form of themes and then narrated. Data validity test used data triangulation techniques.
The research participants in this study are 3 elderlies aged 75 and 76 years old who live in Salatiga. MMSE test results and clinical diagnosis show that participants were classified as elderly with mild dementia Alzheimer's. The following table lined out the sociodemographic identity of three participants (Table 1)

Based on the result of self and family reports, observation of the physiological, emotional, and cognitive abilities of the three participants, 7 sub-themes emerged:

\section{Physichal Disorder}

All three participants had experienced physical disorders but only one participant complained more about this disorder than the other two. Complained physical disorders consist of back pain, having fever sometimes, dizziness, and physical weakness. The following are excerpt from the interview:

"saya ini sudah lama loh sakit-sakitan terus ini, sampai saya ndak pernah berangkat ke gereja, kelamaan duduk sakit nanti pusing, ndak kuat" (P1)

"kabar baik, kadang-kadang saya lagi pusing sakit-sakitan" (P2)

"ndak ada jarang” gak enak badan "anu jarang sakit jarang. jarang” ke dokter "ndak sakit, jarang” karena ga sering sakit makanya jarang ke dokter (P3)

('I've been sick for a long time now, to a point where I don't go to church anymore, if I sit too long I get really dizzy, and I can't stand it" (P1)

"good news, sometimes I'm also sick when I get dizzy" (P2)

"not rarely feeling ill, I don't get sick often go to the doctor not sick, rarely so because I rarely get sick I don't go to the doctor" (P3))

\section{Life Satisfacation}

Participant 1 (P1) reported low life satisfaction because she claimed that she was not a happy child and now she lived alone. In addition, she also claimed that the experienced physical disorders cause dissatisfaction on her life. Below is the excerpt from the interview:

"Ga ada aku ini kesenangan aku. Iya! Hanya adanya susah sedih terus menerus" (P1)

("Nothing, I am my own pleasure. Yes! There are only problems and constant sadness" (P1))

In contrast to P1, participants 2 and 3 (P2 and P3) claimed they're happy with their family, experiences at school, work, and achievements. Excerpt from the interview are as follows: "senang sekali wong istrinya terus ikut saya, ya nurut terus sih di mana saja jadi kapolsek ikut” (P2)

"ini semua waktunya senang, ini anak saya semua senang kok, dia kerja sudah senang. Anak saya di Jakarta. Saya gak milih-milih, seng penting biasa makan. Sekolahnya anak saya tu ndak saya mau, sekolah apa saja terserah mereka" (P3)

('I'm very happy because the wife always follows me, she always obeys wherever so the police follows (P2

\section{Results}


"It's a happy time, all my children are happy, they are working so they are happy. My child in Jakarta. I am not Cognitive Failure

All participants were confused and not able to answer questions immediately. They have difficulty explaining the family tree, failing to recognize objects, failing to remember age, and difficulty in differentiating dates from years. Sometimes they are stuck with the previous conversation so that the answers do not match the questions asked. They tend not to recognize the environment and other people. The three participants had difficulty speaking in accordance with applicable sentence structure (subject-verb agreement). They also failed to remember others so during the interviews, researcher need to continuously re-introduced one-self and re-explaining the purpose of the study. These are the excerpts from the interview:

"Mbah anak yang ke berapa? berapa bersaudara?"

"Pertama, empat bersaudara, saya trus adik saya yang di Getasan ini masih trus mamanya ini, piye toh, saya, adek saya yang di Getasan trus mamanya ini, trus adiknya lagi tapi meninggal, adenya mamanya ini, ade saya juga” (P1)

"Apa yang sakit?"

"Ya kalo saya datang mesti kan minta tagihan" (P2)

"Pekerjaan saya anu agraria. Ibu itu kalo apa itu ya nganu loh hampir nganu hampir tempat ke hampir nganu tapi gini loh maksudnya aduh patah-patah" (P3)

("which Children are you? how many siblings do you have?" "First, I have 4 siblings, myself and my younger sibling who is in Getasan still with our mother, wait, me, my sibling in Getasan and our mother, and her younger sibling but have passed away, the mother's younger sibling is also my younger sibling" (P1)

"What hurts?"

"Well if I come I have to ask for the bill" (P2)

"I work in agrarianism. Our mom is what uhmmm almost uhmm almost at uhmmm but this is what I mean, oh no, I'm staggering" (P3))

\section{Discussion}

\section{Subjective Well-Being}

Based on cognitive function measurement using $\mathrm{MMSE}^{21}$ all participants are classified in mild cognitive decline. Based on their age, the result of this study in line with Purnakarya ${ }^{22}$ who claimed that there is a relevant relationship with age increase and dementia. In addition, P1 and P2 also reported on other physical disorders.

Complaints on physical disorders is in line with Indonesian Ministry Data Center ${ }^{12}$ which explained that the increase in age will result in the decrease of physiological functions and health problems. In contrast with P1 and P2, P3 claimed that he is rarely sick since he was in his youth due to physical activity. Regular physical activity affects the development of chronic diseases (reducing secondary effects), recovery of functional capacity and increase of life expectancy. ${ }^{23}$ Based on physical problem complaints, P1 with higher MMSE value is the ones who protests the most. Zank and Leipold ${ }^{24}$ stated that understanding on physical health problem increase when cognitive function decline.
Complaints on physical disorders affect the participants in expressing their satisfaction in life. This condition is supported by Zank and Leipold ${ }^{24}$ who argued that the interaction of physical illness and cognitive function cause significant changes in depressive symptoms and life satisfaction. This condition also in line with Hariyanti et $\mathrm{al}^{25}$ who claimed that there is a relationship between depression and frail condition. In other words, variations on participants' well-being is determined by their state of cognitive function if physical health is very low in comparison. Higher life satisfaction is expressed by P2 and P3 who have lower value in MMSE. This condition justifies Zank \& Leipold's opinion ${ }^{24}$ that those with lower cognitive decline do not recognize the limitation or deficit of coexistence with their illness.

In addition to physical problems and cognitive function decline, participants' subjective well-being is also affected by family role, dominant social support ${ }^{24}$, basic needs fulfillment and pleasant life experience. ${ }^{26}$ Diener $^{26}$ claimed that individuals whose basic needs are fulfilled will enter post-materialistic phase that focus on self-fulfillment in their later life hence the admitted life satisfaction.

Satisfaction on important domains is also important to subjective well-being. Research findings showed that P2 and P3 are more satisfied due to their achievement in schooling and work. On the other hand, P1 reported on a more dominant unpleasant feelings/unsatisfied that resulted in low SWB. Along this line, Diener ${ }^{26}$ stated that high SWB is expressed by individual with more pleasant experiences and less unpleasant moment in school and work. Satisfaction with important domains leads to high aspects where individuals strive for excellence based on their own unique potential. ${ }^{27}$

In relation to satisfaction on important domain that lead to positive effects, result of this study shows that P2 and P3 display a higher adaptive preference than P1. Such condition strengthened the meaning of Eudaimonia where individual developed based on their efforts in developing their potential and refer to constant positive relation with their enjoyment of achievement. ${ }^{27}$ Positive effects are found in this study through P2 and P3 who claimed to experience happy moments in their life, high family support, and good social environment. Applying Diener ${ }^{28,29,26}$ perspective, the above mentioned research finding is the best predictors of good subjective well-being. Along this line, Eid and Rand ${ }^{30,}$ also claimed that family contributes to individual SWB.

\section{Healthy Behavior}

All participants experienced changes in behavior, various treatment efforts and cognitive failure. Maulana ${ }^{31}$ viewed healthy behavior through knowledge, attitude and actions to maintain it. MMSE result of the three participants showed that they are in the state of mild cognitive function decline. Alzheimer's Disease International ${ }^{6}$ elaborated that such condition will affect daily life behavior. Participants of this study displayed apathetic behavior, offended, angry, eating problem, myoclonus and sometimes incontinence. These behaviors are in accordance to American Psychiatric Association. ${ }^{21}$ Despite the similarities in their change of behavior. The participants' effort for medical treatment varies. This shows that individual attitude is closely related 
Table 1. Sociodemographic Identity of Participants

\begin{tabular}{|c|c|c|c|c|c|}
\hline Participant & Sex & Age & Family History & Employment and Education History & $\begin{array}{l}\text { MMSE } \\
\text { Result }\end{array}$ \\
\hline $\mathrm{P} 1$ & Woman & 75 years old & $\begin{array}{l}\text { - Married } 2 \text { times } \\
\text { - Has } 1 \text { son } \\
\text { - Current status : divorce } \\
\text { - Live alone }\end{array}$ & $\begin{array}{l}\text { - Graduated elementary school } \\
\text { - Do not have permanent job }\end{array}$ & 58 Points \\
\hline $\mathrm{P} 2$ & Man & 75 years old & $\begin{array}{l}\text { - Married } \\
\text { - Has } 3 \text { Children and } 6 \text { grand children } \\
\text { - Current status : married } \\
\text { - Live together with wife } \\
\end{array}$ & $\begin{array}{l}\text { - Graduated Senior High School } \\
\text { - Retired Chief of Police Sector }\end{array}$ & 40 Points \\
\hline P3 & Man & 76 years old & $\begin{array}{l}\text { - Married } \\
\text { - Has } 3 \text { children and } 3 \text { grand children } \\
\text { - Current status: married } \\
\text { - Live together with wife }\end{array}$ & $\begin{array}{l}\text { - Graduated Senior High School } \\
\text { - Retired Civil Service National Land } \\
\text { Agency }\end{array}$ & 48 Points \\
\hline
\end{tabular}

to their knowledge ${ }^{31,32}$ beliefs, emotion and social influence. ${ }^{26}$

In addition to change of behavior and healthy behavior implementation, all participants also experienced cognitive failure, referring to DSM V guidelines. ${ }^{21}$ The experienced failure cause further disruption in more than one domain in brain function. ${ }^{21}$ Cognitive failure displayed by the participants is the result of biological adaptation where abnormal plaque (beta amyloid) accumulates in the brain and the communication barriers between nerve cells resulted in cells death. ${ }^{6}$

Displayed symptoms due to cognitive failure are slow respond and not answer the questions, difficulty in expressing opinions, unstructured speech/language problem (not in accordance to subject-verb agreement), repetitive information, problem in object recognition, inconsistent answers, memory recall disruption, spatial recognition problem, difficulty in responding to new information and decline in learning capability. Despite their cognitive failure, social cognitive seem to be maintained and they can still remember their childhood, school and work time, marriage and other social relations. This findings confirms Piaget ${ }^{33}$ concept of intelligence. According to Piaget ${ }^{33}$, intelligence is developed through intellectual phases and it refers to biological adaptation, equilibrium between individual and the environment, gradual development, mental activities and capabilities. Another symptom that arises when viewed from Piaget's perspective ${ }^{33}$ is that all participants experienced scheme limitations. This limitation resulted in the participants having child-like context of thinking despite their old age. To add on, these elderlies also experienced problems in assimilation process, accommodation, equilibration, adaptation and both figurative and operative knowledge.

Based on the participants' age, these research findings indicate a failure in the stage of cognitive development according to Piaget. ${ }^{33}$ In such age, the participants should have passed concrete operation phase, instead they are experiencing difficulties in adapting overall image and high egocentric in thinking for having no awareness of other possible thoughts. Adaptation difficulty of the participants is in line with Piaget's ${ }^{33}$ theory of constructivism that focuses on individual activeness in building the knowledge. Piaget also stated that children of the same age tend to make the same mistakes. This phenomenon is also displayed by the three participants where relatively similar cognitive failure occurs due to the likeliness in their pathophysiological condition.

\section{Conclusion}

Participants of this study are elderlies with mild Alzheimer's dementia. Reported high subjective well-being is closely related to the low level of unpleasant emotions during their life journey. Satisfaction on potential based excellence achievements resulted in the emergence of adaptive reference in participants. Low subjective well-being arises when the frequency of emotions exhibited by participants leads to higher negative affects, as a result of feeling unhappy throughout life. Two participants reported better SWB than the other one.

Healthy behavior is strongly influenced by knowledge, demographic factors, personal goals and values, social influence, and access to health services. All participants showed the same behavioral changes. Despite the similarities, the participants have different experiences in implementing healthy behaviors. In addition, all participants also experienced cognitive failure that is also similar in its pathophysiological condition. Thus participants with Alzheimer's dementia experience a decline and even lose the stage of cognitive development.

The limitation in this study is the socio-cultural factor in which the community around the research site considers "forgetfulness" as something natural thus MMSE testing and being a participant in this study were considered unnecessary. In addition, there were some people who felt ashamed to express the condition of families affected by dementia because it is considered a mental disorder. This is due to the caregiver's lack of knowledge regarding Alzheimer's dementia. Furthermore, the long duration of research also influences changes in participants thus changes in participants' characteristics will occur. This could be because, during the duration of the study, the interventions given to the participants have not been able to suppress the rapid development of symptoms experienced.

\section{Acknowledgement}

I acknowledge and highly appreciative of the tremendous support from my family, Mrs. Susana Prapunoto as a UKSW Psychology Science head Master's Study Program, supervisors (Mr. Yulius Ranimpi and Mr. Adi Setiawan), the 
Indonesian Alzheimer's Foundation, the Salatiga Indonesian Alzheimer's Foundation, the three participants and their families, Mr. Ferry Karwur and family, Mrs. Tesa Messakh and family, Opa John Titaley and family, late Oma Martha Daandel, my Classmates in SWCU FKIK 2011 and SWCU Postgraduated Program in Psychology 2016, and housemates and friends in Margosari Salatiga.

\section{References}

1. Sekretariat Jenderal Kementerian Kesehatan RI. Profil Kesehatan RI 2015. Profil Kesehatan Indonesia Tahun 2015. 2016. 125 p. DOI: 10.1111/evo.12990

2. Maria Célia de Freitas, Terezinha Almeida Queiroz JAV de S. The meaning of old age and the aging experience of in the elderly; 2010. 44(2):407-12. DOI: 10.1590/s0080-62342010000200024

3. Pranarka K. Penerapan Geriatrik Kedokteran Menuju Usia Lanjut yang Sehat. Universa Med [Internet]; 2006. 25(4):187-97. Available from: https://univmed.org/wpcontent/uploads/2011/02/kRISPRANAKA.pdf

4. Data WLC-P. World report on Ageing and Health. (C) World Health Organization 2015 All rights reserved. Publications of the World Health Organization are available on the WHO website (www.who.int) or can be purchased from WHO Press, World Health Organization, 20 Avenue Appia, 1211 Geneva 27, Switzerland; 2015. p. 260.

5. Australia A. Apa Itu Demensia? [Internet]; 2016. Available from: Fightdementia.org.aug

6. ADI. Dementia in the Asia Pacific Region Alzheimer's Disease International [Internet]. Dementia in the Asia Pacific Region; 2014. Available from: https://www.alz.co.uk/dementia-in-the-asia-pacific ISBN: 9789241564458

7. Dian Fithria Hidayaty. Pada Lansia Di Kelurahan Sukabumi [Internet]. Hubungan aktivitas fisik dan aktivitas kognitif terhadap kejadian demensia pada lansia di kelurahan sukabumi. UIN Syarif Hidayatullah Jakarta; 2012. Available from: http://repository.uinjkt.ac.id/dspace/bitstream/123456 789/25533/1/Dian Fithria Hidayaty - fkik.pdf

8. Swift J. What is Alzheimer ' s Disease ?; 2009.11. Available

from: https://www.alzheimers.org.uk/download/downloads/i d/3379/what_is_alzheimers_disease.pdf

9. Management T. Research Article Research Article. Arch Anesthesiol Crit Care; 2018. 4(4):527-34. DOI: http://dx.doi.org/10.21776/ub.mnj.2017.003.01.1

10. Maftukhah. Hubungan antara status demensia dengan disabilitas fungsional pada lansia di desa gonilan kartasura naskah publikasi [Internet]. Universitas Muhammadiyah Surakarta; 2013. Available from: http://eprints.ums.ac.id/24184/10/02._NASKAH_PUB LLIKASI.pdf

11. Kartikasari D, Handayani F. Pemenuhan Kebutuhan Dasar Manusia Pada Lansia Demensia Oleh Keluarga. J Nurs Stud [Internet]; 2012. 1(1):175-82. Available from:

https://media.neliti.com/media/publications/89978-IDpemenuhan-kebutuhan-dasar-manusia-pada-l.pdf

12. Kementrian RI PD dan I. Elderly Condition in
Indonesia [Internet]. Report; 2016. Available from: http://www.depkes.go.id/download.php?file=downloa d/pusdatin/infodatin/infodatin lansia 2016.pdf. ISSN: 2442-7659

13. Presiden Republik Indonesia. Rencana Aksi Nasional Lanjut Usia 2009-2014 [Internet]. Direktorat Utama Pembinaan dan Pengembangan Hukum Pemeriksaan Keuangan Negara, 13 Tahun 19982017 p. 1-2. Available from: http://www.bphn.go.id/data/documents/98uu013.pdf

14. Peraturan Pemerintahan RI. UU No. 43 Tahun 2004 Tentang Pelaksanaan Upaya Peningkatan Kesejahteraan Sosial Lanjut Usia. 2004;1-17.

15. Mark McGillivray and Matthew Clarke. Understanding human well-being. In: United Nations University Press [Internet]; 2006. p. 66-89. Available from: http://citeseerx.ist.psu.edu/viewdoc/download?doi=10. 1.1.605.6473\&rep=rep1\&type $=$ pdf. ISBN: 9280811304

16. Heryana A. Perilaku Sehat Dan Promosi Kesehatan. 2016; Available from: http://esaunggul.ac.id.

17. Suriastini, Witoelar F, Supraptilah B, Wicaksono TY, Dwi E. Policy Brief: Angka Prevalensi Demensia [Internet]. Alzheimers Indonesia Scientific Commit; 2016. Available from: https://media.neliti.com/media/publications/283-IDangka-prevalensi-demensia-perlu-perhatian-kitasemua.pdf

18. International AD. Piagam Global Penyakit Alheimer Kita sedang menghadapi kegawatan di bidang kesehatan; 2008. Sept;44:7981-7981.

Available from: https://www.alz.co.uk/sites/default/files/pdfs/alzheime rs-charter-indonesian.pdf

19. Creswell JW. Second Edition Qualitative Inquiry \& Choosing Among Five Approaches Research Design [Internet]. SAGE Publications; 2017. 1-414 Available from:

https://www.academia.edu/33813052/Second_Edition _QUALITATIVE_INQUIRY_and_RESEARCH_DE SIGN_Choosing_Among_Five_Approaches. ISBN: 978-1-4-4129-1606-6

20. Gevi Khairunnisa, Pricillia Putri, Febbealya Cheerson, Fenny Junita, Christiany Suwartono MH. Uji validitas konstruk the modified Mini Mental State-Test (3MS); 2014. 3(5):329-59. DOI: 10.15408/jp3i.v3i4.9320

21. Dilip Jeste P V, Jeffrey Lieberman P-EA, David Fassler T, Rcxser Peele S, Speaker Scott Benson AR, Akaka J, et al. Diagnostic and statistical manual of mental disorders fifth edition dsm-5. American Psychiatric Association; 2013. ISBN: 9780890425541

22. Purnakarya I. Defisiensi riboflavin dan demensia pada usia lanjut. Kesmas Natl Public Heal J; 2011. 6(3):99. DOI: 10.21109/kesmas.v6i3.99

23. Chodzko-Zajko WJ, Proctor DN, Fiatarone Singh MA, Minson CT, Nigg CR, Salem GJ, et al. Exercise and physical activity for older adults. Med Sci Sports Exerc; $2009 . \quad 41(7): 1510-30 . \quad$ DOI: 10.1249/MSS.0b013e3181a0c95c

24. Zank S, Leipold B. The relationship between severity of dementia and subjective well-being. Aging Ment Heal; 2001. 5(2):191-6. 
DOI: $10.1080 / 13607860120038375$

25. Journal M. Cognitive impairment and depression are the most important risk factors for frailty. MNJ (Malang Neurol Journal); 2020. 6(1):19-22. DOI: 10.21776/ub.mnj.2020.006.01.4

26. Diener E. Subjective well-being: The science of happiness and a proposal for a national index. Am Psychol; 2000. 55(1):34-43. DOI: 10.1037/0003066X.55.1.34

27. Samman E. Psychological and subjective wellbeing: a proposal for internationally comparable indicators. OPHI Work Pap Ser; 2007. 1-54. DOI: https://doi.org/10.1080/13600810701701939

28. Diener E. Culture and well-being the collected works of ed diener. 38th ed. London New York: Springer Science+Business Media B.V.; 2009. 1-296 p. ISBN: 9789048123513

29. Diener E, Tay L. Evaluating life satisfaction measures theory and validity of life satisfaction scales. Soc Indic Res; 2012. DOI: https://doi.org/10.1007/s11205-0120076-y

30. Michael Eid. and RJL. The Science of subjective wellbeing. In: Choice Reviews Online; 2008. 45-5867-455867. DOI: $10.5860 /$ choice. $45-5867$

31. Maulana HDJ. Promosi Kesehatan. Jakarta: Penerbit Buku Kedokteran EGC; 2009. vii-271. ISBN: 978979-448-959-8

32. Mahwati Y. Determinants of multimorbidity among the elderly determinan multimorbiditas pada populasi usia lanjut di indonesia. J Kesehat Masy Nas; 2014. 9(2):187-93.

DOI: http://dx.doi.org/10.21109/kesmas.v9i2.516

33. Suparno DP. Teori perkembangan kognitif jean piaget. Yogyakarta: penerbit kanisius; 2001. 5-155 p. ISBN: 978-979-672-799-5 